\title{
Ovid, Race and Identity in E. L. Doctorow's Ragtime (1975) and Jeffrey Eugenides's Middlesex (2002)
}

\section{Tessa Roynon ${ }^{1}$}

Published online: 18 February 2019

(c) The Author(s) 2019

Ovid is a significant presence in numerous American novels of the twenty-first century. Though this is rarely discussed by critics - who tend to focus on Homeric, Virgilian and tragic allusions instead - the Metamorphoses is an important intertext in works as various as Philip Roth's The Human Stain (2000), Junot Díaz's The Brief Wondrous Life of Oscar Wao (2007) and Toni Morrison's God Help the Child (2015). Ovid's preoccupation with the themes of desire, transition, transgression, violence and subversion readily lends itself to novelists' diverse explorations of modern and contemporary, national and transnational American identities and experience.

This article takes as its starting point the engagement with Ovid in two greatly feted American novels published more than twenty-five years apart: E. L Doctorow's Ragtime, of 1975, and Jeffrey Eugenides's Middlesex, of 2002. ${ }^{1}$ It is surprising that although these novels have much in common, in that they both deploy postmodern voice(s) to examine conceptions of changing identity in the rapidly modernizing America of the twentieth century, critics have rarely considered them together. Less surprising, although also under-analysed by critics, is Ovid's presence in each of these profoundly playful chronicles of individual and national transformation. A particular reading or understanding of the Metamorphoses - in which the poem is taken to epitomize the flux, the fluidity and the constructed nature of modernity - underpins a range of modern and contemporary American texts concerned with these themes. This version of Ovid both shapes and is shaped by Doctorow's portrait of the Progressive Era (from the early 1900s to the end of World War One) in New York City, New York State, Philadelphia, Massachusetts and Detroit, and it also shapes and is shaped by Eugenides's mock-epic account of the decades-long

1 E. L. Doctorow was born in 1931 and died in 2015; Jeffrey Eugenides was born in 1960.

Tessa Roynon

tessa.roynon@rai.ox.ac.uk

1 Rothermere American Institute, University of Oxford, 1a South Parks Road, Oxford OX1 3UB, UK 
assimilation of the Stephanides family, in which the narrator's grandparents emigrate from eastern Greece (now Turkey) to Detroit in the $1922 .^{2}$

Although these novels share a preoccupation with the personal, political and cultural transformations that define twentieth-century American experience, they are unlike each other as well as alike. While the breakneck-paced story of the minimalist Ragtime (which features a WASP nuclear family, a Jewish immigrant family, and an African American family) is told through a dispassionately toned omniscient narrator, the unashamedly expansive or 'maximalist' Middlesex is told through the emotionally involved first person narrative voice of Callie/Cal. Callie/Cal, meanwhile, is a biologically intersex character who interweaves the immigration/assimilation narrative with an account of her/his transition from 'living as a girl' (performing a female gender) to 'living as a boy and young man' (performing a male gender) in line with the changes taking place in her/his body. Despite their differing narrative structures and emotional registers, however, both novels exemplify prototypical postmodernism in their disregard for the distinction between 'art' and 'reality'. Doctorow (to a greater extent) and Eugenides (to a lesser) each gleefully intersperse historical and fictional events, and stage encounters between historical figures with imagined characters, with a conscious disregard for 'truth' and 'falsehood'. ${ }^{3}$ Both authors simultaneously, and not coincidentally, deploy a prototypical post-1970 reading of the Metamorphoses - one which emphasizes ubiquitous, cataclysmic change as well as the Roman poet's ludic energy. This Ovid refracts both authors' explorations of human desire and sexuality; of the numerous processes that capitalism involves (technology, industry, mobility, immigration, the shifting formations of class, gender and race identities); and of the interplay between all of these with art or representation itself. ${ }^{4}$

In comparing the uses to which the Metamorphoses is put in these two complex texts, this article sets out to do three things. First, it maps out what I am terming the 'Ovidian dynamic': a late twentieth-century construction of Ovid's poem, its thematics and its formal qualities that is particularly compelling in specific American contexts and that these novels both articulate and depend on. Next, it explores the role of this Ovidian dynamic in the politics of the two novels. Focusing initially on

\footnotetext{
2 On Ovid in Ragtime see D. Garrison, 'Ovid's Metamorphoses in E. L. Doctorow's Ragtime', Classical and Modern Literature: A Quarterly, 17, 1997, pp.103-11; T. Ziolkowski, Ovid and the Moderns, Ithaca, 2005, pp. 164-6. For a brief mention of Ovid in Middlesex see R. Carroll, 'Retrospective Sex: Rewriting Intersexuality in Jeffrey Eugenides's Middlesex', Journal of American Studies, 44, 2010, pp. 187-201 (189). Carroll does not note the misattribution to Ovid that I discuss at the end of this article's first part (see also n. 10).

3 On Ragtime as postmodern see for example L. Hutcheon, A Poetics of Postmodernism: History, Theory, Fiction, London, 1988, pp. 135-6; F. Jameson, Postmodernism, or the Cultural Logic of Late Capitalism, London, 1991, pp. 21-4; T. Savvas, American Postmodernist Fiction and the Past: Contemporary Satire, London, 2011, pp. 125-55. On postmodernism and/or playfulness in Middlesex see D. Brauner, 'No Man's Land: the Transgendered Voice in Jeffrey Eugenides's Middlesex and Rose Tremain's Sacred Country', in Cross-Gendered Literary Voices: Appropriating, Resisting, Embracing, ed. R. Kim and C. Westall, London, 2012, pp. 148-63; J. McGowan, 'Ways of Worldmaking: Hannah Arendt and E. L. Doctorow Respond to Modernity', College Literature, 38, 2011, pp. 149-57.

${ }^{4}$ For an invaluable overview and critique of postmodern (and post-1970) readings of Ovid, see V. Rimell, 'After Ovid, After Theory', which is the final article in this special issue.
} 
Doctorow's and then on Eugenides's representation of African Americans and the struggle for black equality, it argues that the earlier novelist successfully deploys the radical potential in the thematics of transformation and the stance of playfulness, and thereby envisions an altered racial landscape. Eugenides, on the other hand, ultimately excludes black Americans from the processes of metamorphosis and change which are available to everyone else in his text. As a result, the race politics of his work are ultimately conservative (perhaps even regressive). Lastly, this article builds on those two close readings to explore the paradox that it is the earlier novel, Ragtime - the one that is at once consistently postmodern and most consistently 'Ovidian' - that makes a radical political intervention. By contrast Middlesex, a novel in which the author engages both postmodernism and the Metamorphoses only partially and ambivalently, eschews the radicalism that it leads us to expect.

\section{Representing Modern America through the 'Ovidian Dynamic'}

In his 2005 book, Ovid and the Moderns, Theodore Ziolkowski gives a virtuoso account of the changing reception of the Roman poet over time:

From the ancient tenerorum lusor amorum, the medieval Ovidius Christianus and Ovid moralisé, and the Ovidius redivivus and Ovide travesti of the Renaissance, Ovid has progressed by way of Ovid baroque'd and rococo'd to such recent manifestations as Ovid eroticized, nationalized, psychologized, and trivialized. ${ }^{5}$

His assertion that 'every age gets the Ovid it deserves', however, implies a passivity that belies the more persuasive thesis that every age or moment constructs the Ovid that it wants or needs. ${ }^{6}$ Ragtime and Middlesex exemplify this point in the ways that they at once rely on an accepted contemporaneous understanding of the Metamorphoses and, in themselves, do much to reify that understanding. Ragtime in particular both articulates and puts to use an 'Ovidian dynamic' - an energizing force in which the thematics of change and changeability are articulated through a wide-ranging playfulness - that expresses the dizzying nature and pace of national and personal transformations in modern America. ${ }^{7}$ The 'postmodern Ovid' that emerged from the 1970s onwards, then, is a construction of novelists as much as of the Latinist scholars who were, in this decade, gradually working their way towards this formulation. ${ }^{8}$

\footnotetext{
5 Ziolkowski, Ovid and the Moderns (n. 1 above), p. 225.

6 Ibid.

7 In this essay I am using 'Ovidian' as shorthand both for the Ovid who authored the Metamorphoses, and as a descriptor of the Metamorphoses itself, following M. Hoffman and J. Lasdun in After Ovid: New Metamorphoses, London, 1996.

8 See T. Roynon and D. Orrells, 'Preface' to this special issue, for an account of the history of 'the postmodern Ovid' in Latinist scholarship. See also Rimell (n. 4 above). Although the 'postmodern Ovid' was not fully established, named or recognized as such in classical scholarship until the late 1980s and early 1990s, C. Martindale dates the gradual emergence of a 'postmodern Ovid' in scholarly articles by Latinists to 1975; see his Redeeming the Text: Latin Poetry and the Hermeneutics of Reception, Cambridge, 1993, p. 61 (n. 8). Interestingly, 1975 is the year in which Ragtime was published.
} 
Explicit allusion to literary texts and authors is not a prominent feature of Ragtime as a whole. As Ziolkowski and David Garrison have separately documented, however, Doctorow notably devotes an entire chapter, Chapter 15, to the fact that the 'little boy' (through whom much of the narrative is focalized) learned 'stories from Ovid' from his grandfather. Grandfather, who just happens to be 'a retired professor of Greek and Latin', ${ }^{9}$ tells the boy 'stories of people who became animals or trees or statues. ... stories of transformation. Women turned into sunflowers, spiders, bats, birds; men turned into snakes, pigs, stones and even thin air'. 'The boy did not know he was hearing Ovid', Doctorow continues, 'and it would not have mattered if he had known'. ${ }^{10}$ Beyond the unmissable dialogue that this passage sets up between Ragtime and the Metamorphoses, it is important to note first the way in which Doctorow himself never mentions the title of the Latin poem, but instead uses 'Ovid' as a shorthand or synonym for it. Second, ironically enough, Ovid's status and authority as author here are irrelevant: 'it would not have mattered', it would be neither here nor there, if the boy had known the name of these stories' creator. The Ovidian dynamic that informs Ragtime, Middlesex and many other literary treatments of late twentieth- and early twenty-first-century America is in microcosm here. It is not so much an intertextuality, defined by specific quotation or allusion, as a looser relationship with an 'Ovidian' energy, or sensibility, or ethos or stance.

As Garrison has usefully documented, there are of course occasional direct allusions to mythological figures from the Metamorphoses in Ragtime - the escape artist, Houdini, for example, conducts one of his performances in a room decorated with 'Flemish tapestries of Actaeon being torn apart by dogs'. ${ }^{11}$ The implied association of the voyeuristic or 'peeping' 'Younger Brother' with Actaeon strengthens the affinity between Doctorow's Evelyn Nesbitt and Ovid's Diana while, as Garrison notes, J. P. Morgan is implicitly compared to Midas; Houdini himself to Icarus, and so on. ${ }^{12}$ My own concern, though, is less with this indisputable symmetry between the casts of characters in the Ovid and the Doctorow, and more with the 'Ovidian worldview' that the American author goes on to expound, and to attribute to the little boy, in the remainder of the novel's all-important Chapter 15. These three-and-a-half pages stand out in the novel for being unusually reflective, philosophical, and analytical, and for slowing down the text's otherwise frenetic pace. ${ }^{13}$ In them we learn how the spirit or essence of the stories of the Metamorphoses have shaped in the boy an outlook that we might readily call 'postmodern': we are told that he learned to recognize in his Progressive Era world 'the instability of both things and people'; 'the endurance of a duplicate event'; that 'the forms of life were volatile and that everything in the world could as easily be something else'; and that 'the world composed and recomposed itself constantly in an endless process of dissatisfaction'. ${ }^{14}$ The little boy's new discoveries about

\footnotetext{
9 E. Doctorow, Ragtime, Harmondsworth, 1996, p. 56.

10 Ibid., p. 97.

11 Ibid., p. 28.

12 Garrison, 'Ovid's Metamorphoses' (n.1 above), pp. 107-11.

13 On the significance of the character of the boy, and his implied role as (ethical) narrator, see C. Walker Bergström, Intuition of an Infinite Obligation: Narrative Ethics and Postmodern Gnostics in the Fiction of E. L. Doctorow, Frankfurt, 2010, pp. 65-9.

14 Doctorow, Ragtime (n. 9, above), pp. 97-9.
} 
the powers of reflexivity (the mirror he looks in), of art (the films he sees at the local cinema) and of the imagination (his thoughts become reality about the hairbrush and the window) are all implicitly attributed to his immersion in the 'stories from Ovid'. Here then, Doctorow, writing in the early 1970s, uses Ovid to view the 'modern' age in America, the first decades of the so-called 'American' or twentieth century, through a postmodern lens. In Ragtime the Ovidian dynamic is inseparable from, or indispensable to, the author's witty, detached and playful representation of a fast-changing, endlessly reflexive world in which, apparently at least, all things are possible.

Less excited than Doctorow by the riches that a postmodernist can locate in the Metamorphoses, Ziolkowski declares, somewhat wearily, that Ragtime 'invoked the principle of change and transformation so dear to the countercultural generation of the sixties'. ${ }^{16}$ While Jeffrey Eugenides (not born until 1960) is clearly not of the 'sixties generation' himself, his protagonist in Middlesex, Callie/Cal, is a teenager during that decade, and the novel itself is centred on the changes and the transformations characterizing the American 1930s-60s. Although Ziolkowski does not discuss Eugenides's text (presumably its appearance, in 2002, was too late for inclusion in his study), Ovid's Metamorphoses is explicitly invoked in that novel in the formal setting of Callie/Cal's classroom. There, the protagonist delights her teacher by attributing a Latin quotation to 'Ovid, Metamorphoses. The story of creation'. ${ }^{17}$ It is easy to pass quickly over this moment, given that (in contrast to Ragtime) the entire novel is consciously overladen with often joyfully incongruous allusions to classical myth and literature. But when the narrator goes on to play the part of 'Hermaphroditus' in the San Francisco sex show, ${ }^{18}$ the voice-over relays a detailed version of that character's encounter with Salmacis. Eugenides ensures us we cannot overlook the significance of Ovid here by having his narrator observe: 'Ovid doesn't tell us how [Hermes and Aphrodite] felt after their child went missing'. ${ }^{19}$ Throughout the novel, Eugenides plays with the same Ovidian dynamic that Doctorow articulates - a Metamorphoses-inspired valorization of political, cultural and personal change in which instability, fluidity and reflexivity are (apparently) the celebrated norms. As I shall go on to demonstrate, however, Eugenides ultimately restricts access to this 'Ovidianism', and limits the potential for self-reinvention and successful maturation, to the white, Greek American (and by-now-living-as-a-male) protagonist who is his central concern. In ultimately abandoning an Ovid-like, postmodern and constructed worldview that he has previously reified, Eugenides undermines the incipient subversiveness in his text.

My specific focus in the remainder of this article is on how the Ovidian dynamic - the concept of transformation, a faith in art's power, and the stance or technique of playfulness - are borne out, or not borne out, in the texts' respective representations of African Americans and of the black struggle for a new racial politics. In other

\footnotetext{
15 Ibid., p. 97.

16 Ziolkowski, Ovid and the Moderns (n. 1 above), p. 166.

17 J. Eugenides, Middlesex, London 2002, p. 198.

18 Ibid., p. 481.

19 Ibid., p. 492.
} 
words, my discussion does not attempt to map the two modern novels tidily onto the Metamorphoses, nor vice versa. Instead, it examines the role of Ovid's presences and absences in these texts' political work. Though both authors enlist black Americans in their grand schemes of personal and national metamorphosis, Middlesex is far more problematic in this regard than is Ragtime. Through the combination of Coalhouse Walker's heroic (though violent) resistance and self-sacrifice together with the survival of his infant son, Doctorow ultimately constructs a vision of black emancipation and an improved racial or interracial paradigm. Eugenides's treatment of African Americans, on the other hand, is very different. Although tellingly underdiscussed by scholars, who have congregated towards the more obvious thematics of gender, intersex, and ethnicity, it is important to acknowledge the fact that Middlesex dabbles with but eventually abandons the concepts of both black emancipation and a just racial politics. The central section of the novel depicts Callie/Cal and her/his family both observing and interacting with African Americans, often empathizing with their disadvantage, even identifying with them. While Eugenides (momentarily) implies that in the 1930s-1960s there were significant commonalities between Greek immigrants and black Americans, all of whom were trying to change their lives for the better, the novel ultimately drops or forgets about the black cause. Discomfortingly, it therefore implies that transformation, in all the virtuoso Ovidian resonances with which Eugenides imbues it, is a viable process for everyone and everything in America except for black people.

In the following analysis of the way the black political struggle is represented first in Ragtime and then in Middlesex, then, this article brings to bear time-honoured questions that are frequently asked of both Ovid and of postmodernism, and indeed of the 'postmodern Ovid': can these perspectives or approaches, valorizing indeterminacy, playfulness, instability and flux as they do, ever envision genuine political change? What are the political possibilities of the postmodern aesthetic? Applying the key question that Goulimari asks of postmodernism to these two novels that are apparently defined by an Ovidian worldview, can either Middlesex or Ragtime contain within them a viable 'theory of agency'?. ${ }^{20}$ In the next part of this essay I will suggest that Ragtime can and does envision genuine agency for its black protagonists (as well as white), and that therefore it delineates at least the possibility of genuine political change. In the third part I will argue that Middlesex, by contrast, reserves real change and viable agency only for its white protagonist. Eugenides uses racial difference and black politics, it transpires, merely as metaphors or ancillary presences that are temporarily enlisted in the service of Callie/Cal and of his central thematics of double-voicedness. ${ }^{21}$ In fourth and final part of the article, I illuminate and discuss the paradox that Ragtime is at once the more wholly postmodern novel of

\footnotetext{
20 P. Goulimari, 'Introduction', in Postmodernism: What Moment?, ed. P. Goulimari, Manchester, 2007, pp. 1-13 (7). For further discussion of the relationship between agency, political change and postmodernism see D. Fowler, Roman Constructions: Reading in Postmodern Latin, Oxford, 2000, p. 31; L. Hutcheon, 'Gone Forever, but Here to Stay: The Legacy of the Postmodern', in Postmodernism, ed. Goulimari (this note), pp. 16-18; and G. Matthews, Ethics and Desire in the Wake of Postmodernism, London, 2012, p. 2 .

21 On the 'hermaphroditic voice' in Middlesex see Brauner, 'No Man's Land' (n. 3 above), p. 151.
} 
the two, the novel that most overtly and continuously allies the Ovidian worldview with the postmodern one, and at the same time the one that conceives of real change in America's racial landscape. Middlesex, on the other hand, while at first appearing to privilege both the concept of transformation and the liberations of postmodernism, is found (as many critics have discussed in relation to gender politics) to be only fleeting in its endorsements of playful radicalism. Ironically enough, the result of such pragmatism is that the dominant worldview is ultimately reinscribed, and the idea of a transformed racial politics is forgotten as if it were a substance-less game.

Close analysis of Eugenides's first explicit invocation of Ovid in the text contains clues to the fact that the novelist will (unlike Doctorow) go on to abandon or incompletely deliver on the potential for playful transformation that the Metamorphoses constitutes. For the quotation that Callie/Cal attributes to Ovid - 'ex ovo omnia' (everything comes from an egg) is in fact not from the Roman poet at all. ${ }^{22}$ As the biological determinism of this axiom implies, it has nothing to do with the Creation story in the Metamorphoses, and is a distinctly un-Ovidian sentiment. ${ }^{23}$ Doubtless Eugenides knows this only too well, enjoying teasing his readers while also staging a faux-Latin pun, in which 'ex ovo omnia' might mean 'everything comes from Ovid'. As this article demonstrates, however, while 'everything' might indeed 'come from Ovid' and his transformative playfulness in Ragtime, in Middlesex only a white (and 'male') agency, ironically un-Ovid-like in its stability, is finally realized from the Roman poet's vision. Viable, ongoing black agency in Middlesex does not 'come from Ovid' nor from anywhere else, for it is never present in this novel at all.

\section{Ragtime: Envisioning a Transformed Racial Politics}

In his depiction of the early twentieth century in the USA, E. L. Doctorow is interested in the fluidity of identity and the human capacity for change, as well as in the role of art in these processes. It is significant that while the escape artist, Houdini punctuates the plot of Ragtime with a range of transformative acts, this same character agonizes at length about the futility and the disengaged nature (as he himself perceives it) of his artistry: 'there was a kind of act that used the real world for its stage. He couldn't touch it. For all his achievements, he was a trickster, an illusionist, a mere magician. What was the sense of his life if people walked out of the theatre and forgot him?'. ${ }^{24}$ But neither Doctorow himself, nor the majority of the scholarship on this novel, shares Houdini's scepticism about the power of imagined worlds to shape the 'real' one. Despite - or indeed, thanks to - Doctorow's highly stylized and detached tone, his trademark clipped, declarative and impassively toned sentences

\footnotetext{
22 Eugenides, Middlesex (n. 17 above), p. 198.

23 'Ex ovo omnia' is the formulation of the English physician and thinker William Harvey (1578-1657), who inscribed the line on the front cover of his book published in 1651, On Generation. See Walter Pagel, William Harvey's Biological Ideas: Selected Aspects and Historical Background, Basel, 1967, p. 314.

24 Doctorow, Ragtime (n. 9 above), p. 82.
} 
which create an unambiguous non-realism, the novel evidences a sincere engagement with 'real' politics from the outset. ${ }^{25}$ The wit and playfulness that underpin the text (and that are one element of its multi-faceted 'Ovidian dynamic') are fundamental to rather than either detrimental or irrelevant to its politically engaged vision.

Although Doctorow's representation of the immigrants' voyage to America, their transition through Ellis Island, and their gradual assimilation is a set-piece 'tale of transformation', it nonetheless involves genuine protest at their poverty and at the way they are viewed (or overlooked) by pre-existing New Yorkers. Doctorow emphasizes that artistic processes are key to these people's resilience and survival: despite their insanitary and overcrowded living conditions and their bleak economic prospects, they learn the piano, they carve stones for the streets, they sing and tell jokes. Further on, in his depiction of the Ford factory assembly line, the novelist in turn demonstrates the role of his own artistry in asking important political questions, and in defending the dignity and the rights of the individual. This scene, which is similar to Eugenides's treatment of the same watershed moment in industrial production, recalls not any specific moment in the Metamorphoses, but rather Ovid's way of paying attention to the details of the processes of creation and change (epitomized, for example, in the detailed description of how Daedalus makes Icarus's wings in Metamorphoses VIII). ${ }^{26}$ Doctorow tunes in to the innovation of the assembly-line production system, whereby 'the man who puts in a blot does not put on the nut', and the 'inventor' experiences 'ecstasy' because 'he had caused a machine to replicate itself endlessly'. ${ }^{27}$ Yet, crucially, the author also comments briefly but with powerful understated anxiety on the political impact, the impact on each individual, of this new technological system: it demands "not only that the parts of the finished product be interchangeable, but that the men who build the products be themselves interchangeable parts'. ${ }^{28}$ And just as Doctorow aspires towards validating the individual dignity of each group member - whether this be a group of arriving immigrants or a group of factory workers - he also aspires, through his art, to generating collective good from his focus on the specific, named individuals who are the protagonists in his novel.

Scholarship on the politics and ethics of Ragtime have focused primarily on two figures: the Jewish central character known as Tateh, an artist and later a film maker who goes on to marry Mother; and the principal African American character Coalhouse Walker, a pianist-turned-guerrilla activist who gives up his life to a firing squad but whose young son lives on and lives happily at the novel's end. Although

\footnotetext{
25 On the relationship between the playful technique of Ragtime and its serious political engagement see Jameson, Postmodernism (n. 3 above), p. 24, where Doctorow is labelled 'the epic poet of the disappearance of the American radical past'. See also Hutcheon, Poetics (n. 3 above), p. 146, in which Ragtime epitomizes 'historiographic metafiction', and Bergström, Intuition (n. 13 above), in which Doctorow epitomizes the 'ethical postmodern' tradition.

26 As Winkler writes, Ovid's Daedalus and Icarus have become the 'mythical ancestors of all technological innovators'. M. Winkler, 'Ovid and the Cinema: An Introduction', in The Handbook to the Reception of Ovid, ed. J. F. Miller and C. E. Newlands, Hoboken, 2014, pp. 469-81 (469).

27 Doctorow, Ragtime (n. 9, above), p. 113.

28 Ibid.
} 
critics are divided as to the implications for Jewish identity of the ways in which Jewish people are represented in the novel, ${ }^{29}$ scholars such as Barbara Foley and John McGowan are in striking agreement about Doctorow's sympathies when it comes to black politics. McGowan endorses Doctorow's own view (expressed in a 1983 interview) about Coalhouse, that he is 'a man who cannot find justice from a society that claims to be just'. ${ }^{30}$ Foley (writing earlier, in 1978) goes further: she suggests that Doctorow (being 'deliberately and outrageously anachronistic') projects the black activism of the 1960s onto the Teddy Roosevelt era and thereby makes Coalhouse a 'proto-Black Panther hero'. ${ }^{31}$ Yet Foley's discussion of the novel goes on to categorize it as one in which style outweighs substance, or as a text epitomizing a postmodernism in which metafictional qualities eclipse political engagement. The result of what she terms Doctorow's 'mannerism', she argues, is that 'the process of historical reconstruction itself, rather than what is being represented, comes to the fore'. ${ }^{32}$ My own reading of the racial politics in this novel contests this view: it highlights the ways in which Doctorow deploys the theme of transformation to insist on a viable black agency, and argues that the novel's aesthetic self-awareness and paradoxically angry playfulness enable rather than prevent its political determinacy.

There is nothing ambiguous, provisional or merely 'mannerist' about the dominant culture's racism in this text - in other words, about the scale of the challenge Coalhouse faces in seeking to transform both his personal situation and America's racial politics as a whole. In its central plot - the interactions between the white family and Coalhouse Walker's family, and Coalhouse's insurgency in response to racist abuse and vandalism of his car - Doctorow depicts both the willed blindness of the WASP family to political reality and the prevailing culture of active prejudice, discrimination and violence. Even though Mother rescues the abandoned black baby and houses both his mother and himself, she interprets their racial difference as a disorderly, contaminating presence that changes everything: 'The Negro girl and her baby had carried into the house a sense of misfortune, of chaos'. Believing that Coalhouse's predicament 'is the kind of problem that would adhere only to a Negro', their belief in his 'monumental negritude' and their essentialist conception of race enables their conservatism. ${ }^{33}$ Far less restrained, meanwhile, is the prejudice of the fire chief, Willie Conklin, of J. P. Morgan, of Father and of District Attorney Whitman, which expresses itself in explicitly racist abuse. ${ }^{34}$

\footnotetext{
${ }^{29}$ M. Persell (in “"The Jews", Ragtime and the Politics of Silence', Literature and Psychology, 42.4, 1996, pp. 1-15), charges Doctorow with a politics of erasure and forgetting with regard to the realities of the Jewish experience. By contrast, B. Roberts (in 'Blackface Minstrelsy and Jewish Identity: Fleshing Out Ragtime as the Central Metaphor in E. L. Doctorow's Ragtime', Critique, 45, 2004, pp. 247-59) identifies an emancipatory 'resonance of violence in the racial experiences of African Americans and Jews' (257).

${ }^{30}$ McGowan, 'Ways of Worldmaking' (n. 3 above), p. 163.

${ }^{31}$ B. Foley, 'From U.S.A. to Ragtime: Notes on the Forms of Historical Consciousness in Modern Fiction', American Literature, 50, 1978, pp. 85-105 (96).

32 Ibid., p. 105.

${ }^{33}$ Doctorow, Ragtime (n. 9, above), pp. 61-2.

${ }^{34}$ Ibid., pp. 242, 176 and 230, for example.
} 
In his depiction of the activist/guerrilla group that Coalhouse forms to subvert and take revenge on the dominant culture for its racism, Doctorow depicts both the formation and the practice of resistance as transformative. It is noteworthy that neither Doctorow himself nor scholarship on this novel expresses any hesitation or anxiety about the guerrilla group's acts of retributive violence (for example in the fire-bombing of fire stations). Coalhouse's resistance movement is both portrayed and read as a site of fluidity, flexibility and dynamism, hence as one fraught with the potential for instigating change. While not explicitly condoning Coalhouse's violent acts and his followers' readiness to contribute to them, Doctorow portrays the way the protagonist 'militarized his mourning', transforming his grief and anger into action. ${ }^{35}$ The novelist depicts the evolution of Coalhouse's followers into an organization which changes its leader's name into a collective noun ('they were so transformed as to think of themselves collectively as Coalhouse'); and he also charts the psychology of the group (Coalhouse's 'controlled rage affected them like the force of a magnet'). ${ }^{36}$ Here the text challenges the rugged individualism and capitalist self-interest epitomized by J. P. Morgan and by the Progressive Age as a whole (as well as by the 'late capitalist' decades in which Doctorow wrote and in which we read). Quite exceptionally for this text, the author even briefly disrupts the otherwise-formal narrative voice to capture the voice and idiom of group members, absorbing their direct speech into his indirect account. ${ }^{37}$

It is significant that Coalhouse Walker's magnetism transcends racial difference. While it is comic and parodic that Younger Brother blackens his face and finds fulfilment as a member of the activist group, through his observation that 'Younger Brother was totally integrated in their community', ${ }^{38}$ Doctorow does make a serious point about the fluid or non-essential nature of racial identity. It is not surprising that when Booker T. Washington pays a visit to Coalhouse and the guerrillas during their occupation of the library, the Tuskegee founder disapproves of Younger Brother's presence and appearance, equating them with 'some minstrel show'. ${ }^{39}$ Here the novelist juxtaposes the solidarity of the 'Coalhouse' collective with the self-transformation that Washington embodies. Enacting a polar opposite version of black identity, Washington has drastically changed his own circumstances ('a struggle up from slavery to self-realization' $)^{40}$ by following the mode of self-improvement valorized by the dominant culture: that of individual hard work and self-reliance. The most significant element of the interaction between these two very different men is Coalhouse's diplomatic but uncompromising response to Washington's plea that he drop his cause. 'I would hope', Coalhouse says, 'that we might both be servants of our colour who insist on the truth of our manhood and the respect it demands'.

\footnotetext{
35 Ibid., p. 203.

36 Ibid., pp. 206-7.

37 Ibid., p. 207.

38 Ibid., p. 206.

39 Ibid., p. 236.

40 Ibid., p. 245.

41 Ibid., p. 238.
} 
Washington is 'stunned' into a near-faint at this attempt to forge an alliance or to find common ground, but Coalhouse's insistence on his own manhood and his own agency typifies the self-belief that has enabled his own heroic self-preservation and self-transformation.

Coalhouse stands out in the novel for his insistence on and claim to the dignity of the human being, irrespective of the specifics of identity. Though viewed by J. P. Morgan before his death as a 'mad black man', ${ }^{42}$ as his words to Booker T. Washington indicate, he refuses to accept the confines that a racialized categorization might confer. Father observes of Coalhouse, when first meeting him, that 'he didn't know he was a Negro'; ${ }^{43}$ he refuses to live according to any pre-defined expectations that that label might impose, and he has escaped the proscriptions of his ascribed identity. Father observes that 'he seemed to be able to transform the customary deferences practiced by his race so that they reflected to his own dignity rather than the recipient's' ${ }^{44}$ While this self-defining pride and unshakeable self-esteem compels us to recognize Coalhouse as an individual (and so as the antithesis of the Fordian 'interchangeable part'), they also inform the intransigence over the desecrated motor car that ultimately contribute to his death. So complete is his agency, however, that he even appears to take control over the end of his life: having secured the restoration of his Ford Model T, he elects to come out of the Library into the street, 'probably' aware that he was about to be shot. ${ }^{45}$

While Coalhouse's death appears particularly heroic when contrasted with the pantomimic, mock-heroic fate of Father on the Lusitania, critiques of 'protest novels' such as Richard Wright's Native Son and Ann Petry's The Street remind us that the death and/or disappearance of a black protagonist, is, in itself, by no means inevitably transformative or emancipatory. Indeed, to apply James Baldwin's argument in 'Everybody's Protest Novel' (1949) to Ragtime would suggest that Coalhouse's demise, however noble, only contributes to the dominant culture's impulse towards the erasure and disappearance of black manhood. ${ }^{46}$ Yet, crucially, Doctorow's insistence that Coalhouse's son survives him and is set to grow up in a transformed racial landscape at the novel's end refutes the idea that black personhood is non-viable in this text. Critics have paid surprisingly little attention to the fact that Coalhouse's final conversation before his death is a quizzing of Father about the baby boy's development: his walking, his talking, his eating, and 'any detail he could think of'. ${ }^{47}$ Ragtime then ends with a not-very-realistic depiction of the white, the African American and the Jewish girl all playing together on the sun-drenched lawn of a Californian stucco house. It is this sight which gives Tateh the idea for his equally

\footnotetext{
42 Ibid., p. 259.

43 Ibid., p. 134.

44 Ibid.

45 Ibid., p. 255.

46 See J. Baldwin, 'Everybody's Protest Novel', in Collected Essays, New York, 1998, pp. 11-18.

47 Doctorow, Ragtime (n. 9 above), p. 252. There is of course a strong tradition within African American literature of novels with endings that emphasize survival and continuity: conspicuous examples include Pauline Hopkins's Contending Forces (1900); and Zora Neale Hurston's Their Eyes Were Watching God (1937).
} 
unrealistic film about a multicultural and economically mixed 'society of ragamuffins' ${ }^{48}$ Both these visions are in the realm of the speculative and the imaginary; they are fantasy in the minds of Doctorow and Tateh in turn. But as all good readers of consummate artists such as Doctorow (and Ovid) should know, their transformative potential is not diminished by their artifice, nor by their being 'unreal'.

\section{Middlesex: Abandoning a Transformed Racial Politics}

There are two central transformations in Eugenides's mock-epic epic, and the author alternates in his relation of both between an Ovidian playful and exuberant mode and an emotionally engaged, psychologically 'realistic' mode. ${ }^{49}$ The plot-defining metamorphoses are first the process by which Desdemona, Lefty and their descendants change from being Greek to being American; and second the process by which Cal changes from living as a girl to living as a boy and man, underpinned by the transitions inherent in his biological intersex make-up. Eugenides momentarily (but only momentarily) connects the experience of Greek immigration and assimilation in 1920s-70s Detroit with the African American struggle for economic and political equality during the same decades. Of the novel's four 'books' or sections, Book II and the first part of Book III include a significant engagement with black Americans who are attempting to transform their own realities. But Eugenides goes on to disconnect the story of Greek assimilation from black/white race politics, and the issue of civil rights or black equality falls quietly, but problematically, away. The novel ends without any vision of a transformed racial landscape, and this provocative absence suggests that the author has in fact merely appropriated the theme of black empowerment in symbolic support of ideas that are his central interest: that of the 'divocalism' that defines postmodernism, and that of the transformation of the 'unraced' (but implicitly white) self. ${ }^{50}$

Though critics have paid little sustained attention to the representation (and lack thereof) of African Americans in this text, several scholars have drawn attention to the novel's ultimate conservatism in terms of gender, sexuality and ethnic identity. In terms of gender politics, Carroll argues that Middlesex 'preserve[s] a normative sexed identity as male and sexual identity as heterosexual', and that it exemplifies 'the ways in which a nominally transgressive narrative can nevertheless remain captive to normative discourses' ${ }^{51}$ My own contention is that this critique applies equally well to Eugenides's treatment of racial identity and politics. The novelist's ultimate relegation of African Americans and the struggle for racial equality to the realm of the metaphorical constitutes a process that Toni Morrison has theorized as

\footnotetext{
48 Doctorow, Ragtime (n. 9 above), p. 270.

49 On the hybrid form and genre of the novel see D. Shostak, "“Theory Uncompromised by Practicality": Hybridity in Jeffrey Eugenides's Middlesex', Contemporary Literature, 49, 2008, pp. 383-412.

50 Brauner, “No Man's Land' (n. 3 above), p.151.

51 Carroll, 'Retrospective Sex' (n. 2 above), p. 188. See also P. Chu, 'D(NA) Coding the Ethnic: Jeffrey Eugenides's Middlesex', Novel: A Forum on Fiction, 42, 2009, pp. 278-93; S. Hsu, 'Ethnicity and the Biopolitics of Intersex in Jeffery Eugenides's Middlesex', MELUS, 36, 2011, pp. 87-110.
} 
'Africanism' and 'black surrogacy'. ${ }^{52}$ That is to say, the African Americans in Middlesex are there not because the author is interested in them in their own right, but so that he can use them to buttress or express certain dimensions of a white subjecthood. The 'Ovidian dynamic' involving change and development, though explicitly invoked several times in the text, is ultimately unavailable to black people in the America that Eugenides depicts.

In its central sections, the novel exhibits two tendencies with regard to its black characters: there is a frequent authorial identification between aspects of Greek American and African American experience; and there is narratorial distance from or ironic perspective on anti-black racism and racial inequality. In the text's final sections, however, the narrative voice allies itself with the Stephanides family's distancing of themselves from the black people with whom they used to interact, and from the black causes in which they used to take an interest. The Greek/Greek American family continue on a transformative trajectory throughout the novel, from the voyage from Smyrna during which Lefty and Desdemona enact their 'self-transformation' and 'reinvent' and 're-create' themselves, to the book's closing pages. ${ }^{53}$ While the white immigrants learn, at Ellis Island 'how to escape the categories [of undesirables]', the novel implies by its sudden turning away from questions of black transformation that black Americans might never escape the 'categories' within which they have been constrained and, worse still, that this does not really matter. ${ }^{54}$

In Book II, Eugenides can hardly avoid the issue of race politics given that he chooses to settle his immigrant family in Detroit. Indeed, at first he appears to take up this cause with gusto. While Lefty and Desdemona are dazzled by their new city, the narrator manifests an authentic anger about the socio-economic effects of racial inequality that the newcomers 'didn't see': 'the workers sleeping on the streets because of the housing shortage, and the ghetto ... teeming with the city's African Americans, who weren't allowed to live anywhere else ${ }^{55}$ This indignant tone reappears some sixty or so pages later, when Cal interrupts his account of Desdemona's journey to the Nation of Islam headquarters to comment on the 'inexorable laws of racism and poverty' evident in the derelict and overcrowded black neighbourhood, and then fast-forwards by forty years to comment on the 1970s' 'no-tax-base, whiteflight, murder-capital of Detroit' in which 'black people could finally live wherever they wanted to. ${ }^{56}$ Eugenides also highlights racial inequality through his depictions of the different sites of labour at the Ford manufacturing plant: whites worked on the soul-destroying assembly line, while blacks worked in the more brutal and dangerous foundry. ${ }^{57}$ There is a similar implicit (though unspoken) narratorial protest in the fact that, when Lefty attends the comically absurd 'Ford English School Melting

\footnotetext{
52 T. Morrison, Playing in the Dark: Whiteness and the Literary Imagination, Cambridge, MA., 1992, pp. 6 and 13.

53 Eugenides, Middlesex (n. 17 above), pp. 69 and 65.

54 Ibid., p. 73.

55 Ibid., p. 88.

56 Ibid., p. 142.

57 Ibid., pp. 96-7. Cf my earlier discussion of the Ford plant and the implicit allusions to Daedalus in Ragtime. The black workers in Middlesex are perhaps more aptly compared with Vulcan/Hephaestus.
} 
Pot' - a ceremony by which he (and also Syrians, Palestinians, Italians, Norwegians Germans and Polish people) formally becomes American - such a transformation is unavailable to the black population of the city. ${ }^{58}$

Wry comedy interspersed with angry indignation continue to characterize the novel's representation of African Americans and racial inequality until the critical moment of the riots of 1967 . For example, the narrator gently makes fun of Desdemona for her stereotyping when she asks herself, on her journey to the silk factory, why the black people she sees are 'Always laughing, .... Laughing, laughing, as though everything is funny'. ${ }^{59}$ Continuing the mild irony directed at his protagonists, Eugenides continues an implicit identification between first generation Greeks and African Americans: when Zizmo and Lefty embark on one of their shady and suspect business ventures, for example, crossing the frozen Lake St Clair as 'the easiest way to Canada', the author playfully invokes the trope of slaves' prototypical underground railroad escape across the frozen Niagara River. ${ }^{60}$ The narrator's voice is then serious and engaged when reporting the race riot of 1943, and Lefty, in his Zebra Room bar, is portrayed as heroic for refusing to serve drinks to white men who boast about a recent lynching. And in its account of the year 1954, the novel is still protesting black socioeconomic disadvantage, noting that 'the Black Bottom was bulldozed to put in a freeway'. ${ }^{6}$

In his depictions of the Zebra Room bar in the 1940s and 50s, Eugenides depicts both friendships between Greek and African Americans, and testifies to cultural interactions and commonalities between the two groups. For example, he claims the Greeks are responsible for the African American tradition of the dream book, and when the activist M.W.C. Grimes (another historical figure) nicknames Callie 'Cleopatra', calling her a Ptolemy and explaining they were 'Greek Egyptians', the author invokes a centuries-old bulwark of black resistant thought which identifies the African American struggle with the historical interconnectedness of Africa and ancient Greece. ${ }^{62}$ Initially, as well, the treatment of the Nation of Islam is respectful (while also slightly incredulous) in tone: in describing its origins the author consults and cites real history books (those by one C. Eric Lincoln and one Claude Andrew Clegg III). ${ }^{63}$ His account of the movement's founder, the endlessly self-transforming Wallace D. Fard/Wallace Fard Mohammed, is based on the historical figure, a man who in 'real life' was of obscure origins, of an unknown ethnicity about which rumours circulated, and who did disappear without trace in $1934 .{ }^{64}$ Fard does appear to have been something of a 'shapeshifter' whose real life was stranger than fiction,

\footnotetext{
58 Eugenides, Middlesex (n. 17 above), p. 104.

59 Ibid., p. 142.

60 Ibid., p. 120.

61 Ibid., p. 200.

62 Ibid., pp. 206 and 229. On this interconnectedness see D. Orrells et al. (ed.), African Athena: New Agendas, Oxford, 2011.

63 Eugenides, Middlesex (n. 17 above), p. 146. See C. Lincoln, Black Muslims in America, $1^{\text {st }}$ ed. New York, 1973; C. Clegg III, An Original Man: The Life and Times of Elijah Muhammad, New York, 1997.

${ }^{64}$ For an account of Fard's life and work in Detroit, see Lincoln, Black Muslims (n. 61 above), pp. 11-16.
} 
and in punning on the name of 'Fard' with another famous Detroit based 'magician' or transformer, Henry 'Ford', the author's scepticism is perhaps not unwarranted. ${ }^{65}$

It is unsurprising that the crucial turning point in terms of the Stephanides family's attitude towards African Americans is the race riots of 1967; at this point Callie/Cal observes (while neither condemning nor condoning) the fact that her/ his grandfather's fear of black people and his taking increasing security measures in their neighbourhoods are increasing. When their erstwhile friend Marius Wyzxewixard throws a Molotov cocktail into the Zebra Room - a violent act that destroys the family business - the Greek Americans' disengagement from and even hostility towards the black struggle is understandable. At first the narrator maintains an ironic distance on her/his family's changing views, however. S/he includes, for example, a self-mocking observation about their conditional acceptance of African Americans on the cusp of the riots: "we wanted to include them in our society if only they would act normal' ${ }^{66}$ Of the family's post-riots move to the predominantly white and gentrified neighbourhood of Middlesex, Callie/Cal observes with disarming selfrecognition and irony that, 'Shameful as it is to say, the riots were the best thing that ever happened to us. Overnight we went from being a family desperately trying to stay in the middle class to one with hopes of sneaking into the upper, or at least the upper middle'. ${ }^{67}$ But what is striking is that the novel as a whole (through Callie/ Cal's increasingly unironized narrative voice) now starts to reflect the family's disengagement from racial politics, and even the narrator's occasional contempt.

The ten-page account of the civil unrest evidences little 'shame' in its unambiguous criticism of rioting African Americans. Eugenides has Callie/Cal describe the violence in a present tense reminiscent of many battle scenes in classical epic. ${ }^{68}$ Together with the narrator's comparison of the unrest to 'countless movies about Ancient Rome or the battles of the Middle Ages', this creates a hyperbolic mood which undermines the seriousness of the violence and its causes. ${ }^{69}$ The narrator's rhetorical question, 'was it a riot or a guerrilla uprising?', is sarcastic about the idea that there might be provocations that legitimate any organized black resistance. ${ }^{70}$ Eugenides portrays the looting as a scene of Bacchic misrule, and suddenly has Callie/Cal describe the young black women on the street in an unappealingly censorious and yet prurient tone. In this focus on the women's 'miniscule skirts' and the 'residues of men between their legs' there is a misogynistic male gaze as well as racism - sentiments which until now have been critiqued rather than endorsed by this text. ${ }^{71}$

To argue that the novel becomes openly hostile to African American activism would be an overstatement. It does, however, become almost silent about, and

\footnotetext{
65 Eugenides, Middlesex (n. 17 above), p. 146.

66 Ibid., p. 240; original italics.

67 Ibid., p. 252.

68 For example, Virgil uses the present tense in depicting the battle between the Trojans and the Rutulians in Book IX of the Aeneid (IX.660 onwards). On Virgil's use of the present tense see K. Quinn, Virgil's Aeneid: A Critical Description, Exeter, 2006, pp. 77-8.

69 Eugenides, Middlesex (n. 17 above), p. 249.

70 Ibid., p. 250.

71 Ibid., p. 236.
} 
certainly indifferent to, racial inequality and the struggle to change that lived injustice. In Book IV there are frequent scenes and locales from which black people and race politics are conspicuous by their inexplicable absence. For example, when Callie/Cal runs away to San Francisco, all the homeless people are white (their faces are 'brown from sun and dirt'). ${ }^{72}$ It would appear that all of those employed in Presto's sex show are also white, and even on the Greyhound bus none of the passengers are black. It is true that in the novel's closing pages, Callie/Cal does once implicitly challenge her/his own recent whitewashing of social reality: on her/his return to Detroit from the San Francisco jail, s/he records one encounter with a non-white person, a 'street corner dude' who is 'suggestive of the peculiar creative energies of [his] home town'. This man's hostility shocks the narrator into realising the extent of the white male privilege he has now assumed: 'I couldn't become a man without becoming The Man'. ${ }^{73}$ Is it possible that this insight exonerates Callie/Cal, and the novel itself, from my charge that they abandon the transformation of racial politics? I would argue that it might have done so, were it not for the reification of white subjectivity and family lineage that follows this encounter and with which the novel ends.

Ironically enough for a novel that has formerly celebrated self-invention, transformative potential and constructedness, the closing vision of Middlesex endorses notions of a stable and fixed genealogy or ancestry - of what Paul Gilroy would call 'roots and rootedness' as opposed to 'routes and routedness'. ${ }^{74}$ It is not the first time that this paradigm is celebrated: at the beginning of Book IV, Callie/Cal shares the beliefs and worldly wisdom s/he has gained through his time at the clinic: 'living sends a person not into the future but back into the past, to childhood and before birth, finally to commune with the dead. ... you enter the body of your father. From there it's only a quick jump to your grandparents'. ${ }^{75}$ This fusion of biological and spiritual continuity is repeated in the novel's final paragraph, when, in accordance with Greek tradition, Callie/Cal blocks the doorway to prevent her/his father's spirit from re-entering the family house. In a moment of transcendent lyricism, Eugenides writes, 'The wind swept over the crusted snow into my Byzantine face, which was the face of my grandfather and of the American girl I had once been. ... I [was] happy to be home, weeping for my father, and thinking about what was next'. ${ }^{76} \mathrm{Such}$ moments compel our attention, not least for their reinscription of one rarely discussed white privilege. Callie/Cal positions himself and draws strength and agency from his knowledge of an unbroken line of ancestry, tradition and cultural transmission; this unbroken continuity is a resource that African Americans - historically displaced through slavery, and so deracinated, ancestorless, and often metaphorically 'homeless', can seldom claim.

\footnotetext{
72 Ibid., p. 472.

73 Ibid., p. 518. See Chu, 'D(NA)' (n. 51, above), p. 292, for a discussion of this scene.

74 P. Gilroy, The Black Atlantic: Modernity and Double-Consciousness, London and New York, 1993, p. 19.

75 Eugenides, Middlesex (n. 17 above), p. 425.

76 Ibid., p. 529.
} 
This moment of exclusivist transcendence illuminates a further irony inherent in Eugenides's punning on 'ex ovo omnia' (the quotation meaning 'everything comes from an egg' that is misattributed to Ovid by Callie/Cal, and that could also implicitly mean, in faux Latin, 'everything comes from Ovid'). In the opening books of Middlesex, everything does come from Ovid: in a world in which everything is provisional, constructed and potentially transformative, it might be possible for everybody to transform themselves. The adult Callie/Cal's rather complacent reflections on her/his past, however, reveal the unconscious and unexamined 'whiteness' of her/ his outlook. 'It wasn't difficult to pour my identity into different vessels. ... I was able to take whatever form was demanded of me', s/he observes, while later claiming that 'each child was a blank slate to be written on'. ${ }^{77}$ In this euphoric celebration of the capacity for self- transformation, the author ignores the fact that such freedom is unavailable to African Americans, whose bodies are already inscribed or encoded by the dominant culture, and so who are forbidden the luxury of a 'blank slate' identity.

These initially unacknowledged limits of the transformative are then laid bare in the novel's closing vision, in which, after all, the protagonists demonstrate that they and all that matters to them do indeed 'come from an egg'. Callie/Cal's apparently casual observation, earlier in the text, that 'the members of my family have always had a knack for self-transformation', ${ }^{78}$ gains an unexpected implication, revealing her/his complicity, however unwitting, in a discourse of 'biology as exclusion'. In fact, Eugenides's ultimate abandonment of the black struggle for transformation, together with the novel's closing emphasis on family (incestuous grandparents and all) and on biology, allies her/his text with more overtly racist American cultural production of the nineteenth and twentieth centuries. In these, the concept of 'family' is a structure and code for guarding against racial intermixing and impurity. ${ }^{79}$ As Shostak persuasively argues, 'the narrative of immigration and incest circles back to Cal's conception and birth" ${ }^{80}$; in this novel, everything both comes from and points back to not Ovid but 'an egg'.

\footnotetext{
77 Ibid., pp. 434 and 478.

78 Ibid., p. 312.

79 As argued for example in J. deVere Brody, Impossible Purities: Blackness, Femininity and Victorian Culture, Durham and London, 1998, pp. 55-8. The familial structure at centre of Middlesex (incestuous grandparents and all) is even implicated in Walter Benn Michaels's critique of nativism in American literature of the 1900s-1940s, in which 'the homosexual family and the incestuous family emerge as parallel technologies in the effort to prevent half-breeds'. W. B. Michaels, Our America: Nativism, Modernism, Pluralism, Durham and London, 1995, p. 75.

${ }^{80}$ Shostak, 'Theory' (n. 49 above), p. 411.
} 


\section{Conclusion - the Political Postmodern: Playfulness, Artifice and Agency}

In considering late twentieth-century receptions of Ovid, Ziolkowski writes with some scepticism of 'a new wave of Ovidianism that was enhanced in the 1980s and 1990 s by the attention of such emerging constituencies as the feminists, the postmodernists, the urban satirists, the multiculturalists, and the aficionados of sex, violence and the fantastic'. He asks, 'Where, indeed, can (Ovid) go beyond the frothy trivializations at the turn of the millennium?'. ${ }^{81}$ My article's exploration of the role of Ovidian transformation and playfulness in Ragtime's and Middlesex's politics of race exemplifies a key premise of Reception studies: that the reception of classical texts is always and already political. My discussion illuminates not the potential and limitations of the Metamorphoses 'in itself', as some kind of 'Ur-text', but the potential and limitations of late twentieth and early twenty-first century fiction's inevitably politicized intertextuality.

This article also leads to some possibly surprising conclusions about the history and the politics of postmodernism itself. Within the conventionally accepted periodization of postmodern literature, Ragtime's publication date of 1975 situates it at the flourishing beginning or the early zenith of the movement, while Middlesex's publication date of 2002 locates it, in turn, in what is conventionally understood as the waning or slow demise of that movement. While Graham Matthews, Linda Hutcheon and Ajay Heble (among others) each attribute that demise in part to a frustration in some quarters with postmodernism's perceived political inefficacy, my readings of Ragtime and Middlesex accord with their challenge to that perception. ${ }^{82}$

My contention that Ragtime protests black inequality and enables black agency while Middlesex ultimately abandons both of those concerns illuminates the fact that it is the earlier, consistently postmodern text, Ragtime, that is the more politically subversive and engaged of the two. Ironically, Middlesex lacks political traction because it is postmodern in its concerns or subject matter more than in its method and execution. Although more overtly emotional and humanist, particularly at its ending, Eugenides's text is ultimately (in Ziolkowski's terms) the more 'frothy' and 'trivial' of the pair. It subsumes real political engagement on race (as well as gender) to its prior interest in changeability and double-voicedness in themselves, before finally abandoning even those in its unambivalent reification of Cal's apparently male Greek American selfhood. That Doctorow's novel is constant in its 'Ovidianism' while Eugenides only dabbles in this dynamic (before reinstating 'ovum' as his guiding source or principle), is very much to the point. Many critics attest to the politically transformative nature of Ragtime's postmodernism, and their readings chime with Doctorow's own observation, in a 1988 interview, that 'if you don't constantly recompose and re-interpret history, then it begins to tighten its grip on your

\footnotetext{
81 Ziolkowski, Ovid and the Moderns (n. 2 above), p. 225.

82 See Matthews, Ethics (n. 20 above), p. 2. L. Hutcheon glosses Heble in, 'Gone Forever' (n. 20, above), pp. 16-18.
} 
throat as myth' ${ }^{83}$ My article is the first to highlight the central role of Ovid's Metamorphoses in this reinterpretative practice, however. Garrison's reading of Doctorow's Ovidian allusions, useful though it is, does not discuss how the novelist's invocation of the Roman poet informs the nature of the text's cultural intervention as much as its method.

Significantly, it is in the all-important and all-Ovidian Chapter 15 of Ragtime that the boy also becomes aware, upon analysing his reflection in the mirror, that he is 'no longer exact as a person'. ${ }^{84}$ The mirror here is a synecdoche for representation or art, and speaks to Doctorow's fascination with art's power to shape reality (just as the figures of Pygmalion, Daedalus and Arachne do to Ovid's similar preoccupation). Ragtime repeatedly explores the political efficacy of the postmodern aesthetic processes it both describes and constitutes: the immigrants who have their photographs taken by Jacob Riis, for example, stand frozen afterwards, waiting 'for their lives to change. They waited for their transformation. ${ }^{85}$ Tateh's powers as creator of silhouettes, meanwhile, as a maker of flick books (an art which literally enables his survival) and of the idealistic films mentioned at the novel's end, reflect the same aesthetic powerfulness as the novel itself. Such films might be termed 'speculative', utopian or 'alternative history', and they reflect Doctorow's faith in the radical potential of his own non-realism. It is the novelist's own 'faith' in art and artifice, and his demonstration of their powers, that enable his speculative radicalism about black agency in the text.

In contrast to Doctorow, Eugenides does not so much deploy the postmodern as discuss it, and this paradoxically diminishes the political efficacy of his novel. While David Brauner argues that the central concern of Middlesex is 'the principle of natural divocalism',

Caroll persuasively contends that the novel ultimately endorses not a doubleness or multiplicity of identities but instead only a single or unified one. As Carroll points out, it is significant that, when comparing herself to Tiresias, Cal describes herself as 'first one thing and then the other', for Eugenides's reading of Tiresias here is itself indicative of the novel's innate conservatism. ${ }^{86}$ To understand the Theban prophet as 'first one thing ... then the other' (although quite accurately reflecting the sequential account of Tiresias's sex changes in the Metamorphoses III) is in fact an unconventional move in the history of this figure's reception. ${ }^{87}$ T. S. Eliot epitomizes the conventional reception of Tiresias as what Ali Smith would call 'being both': as The Waste Land's 'old man with wrinkled female breasts' he is a symbol not of sequential, end-stopped transition but of simultaneity, of being both a man and woman at the same time. ${ }^{88}$ Kate Tempest beautifully expresses this radical

\footnotetext{
${ }_{83}$ Doctorow is quoted in Savvas, American Postmodernist Fiction (n. 3 above), p. 10.

84 Doctorow, Ragtime (n. 9 above), p. 99.

85 Ibid., p. 14.

86 Brauner, 'No Man's Land' (n. 3 above), p. 151; Carroll, 'Retrospective Sex' (n. 2 above), pp. 188 and 191.

87 Eugenides, Middlesex (n. 17 above), p. 3.

88 T. S. Eliot, The Waste Land, in The Waste Land and Other Poems, London 2010, 1. 238. Casid's concept of the Ovidian 'hyphenate' is helpful to this discussion. See J. Casid, 'Alter-Ovid: Contemporary
} 
paradox of multiplicity within active selfhood when she praises Tiresias in her 2014 work, Hold Your Own: 'Tiresias. you hold your own,/each you that you have been'. ${ }^{89}$ The inability of Eugenides's protagonist, by contrast, to hold her/his multiple identities in play reflects the same non-radicalism that prevents racial transformation or viable black agency in this text.

Two further and final contrasts between Ragtime and Middlesex consolidate my claims for the Ovidian efficacy of the one, and the non-Ovidian inefficacy of the other. These are first Eugenides's use of a first-person narrative voice (as opposed to Doctorow's of a third-person), and second, Eugenides's representation of deep emotion in his protagonist, a strategy by which seeks a similar response in his readers. The younger novelist's bid for the reader's sympathy contrasts strikingly with the detachment of Ragtime, which keeps the reader at some distance. When, in sections of the novel such as this one, Eugenides is consciously emotive or non-detached, nonplayful in parts of his novels, he even overtly distances his technique from Ovid's in that regard. With reference to her/his own running away from home, for example, we should recall that Cal tells us 'Ovid doesn't tell us how his parents felt'. ${ }^{90}$ In a deliberate contrast to Ovidian detachment, in the closing sentence of Middlesex in which narrator tells us that s/he was 'weeping for [his] father', the reader is invited to identify and/or empathize with the speaker. ${ }^{91}$ This implies both a kind of realism and a specificity; there is one specific human being here with whom we can and must identify.

By contrast, Doctorow closes his novel with a broadly panning sweep across a range of figures who have appeared in his text, and maintains the narrator's detached thirdperson voice until the end. Bergström has persuasively analysed the 'inclusive' implications of the narrator's detachment and childlike all-encompassing, non-hierarchizing vision and voice. Paradoxically, by not seeking identification and empathy, this book speaks to all and for all. As Bergström observes, Doctorow's novel is 'serious fun'. ${ }^{92}$ Arguably, while Ragtime enlists Ovid's playfulness to non-playful ends, Eugenides instead only plays with the Roman poet and his poem. And it is the later author's failure to take Ovid seriously that guarantees the ultimate conservatism of his text.

OpenAccess This article is distributed under the terms of the Creative Commons Attribution 4.0 International License (http://creativecommons.org/licenses/by/4.0/), which permits unrestricted use, distribution, and reproduction in any medium, provided you give appropriate credit to the original author(s) and the source, provide a link to the Creative Commons license, and indicate if changes were made.

Publisher's Note Springer Nature remains neutral with regard to jurisdictional claims in published maps and institutional affiliations.

\footnotetext{
Footnote 88 (continued)
}

Art on the Hyphen', in Handbook to the Reception of Ovid, ed. Newlands and Miller (n. 24 above), pp. 216-35 (216).

89 K. Tempest, 'Tiresias', in Hold Your Own, London 2014, 23.

90 Eugenides, Middlesex (n. 17 above), p. 492.

91 Ibid., p. 529.

92 Bergström, Intuition (n. 13 above), pp. 68-70. 